\title{
PERFORMANCE AND CARCASS CHARACTERISTICS OF SWINE AT 50 KG FED DIETS WITH DIFFERENT ENERGY LEVELS AND REDUCED LEVELS OF CRUDE PROTEIN ${ }^{1}$
}

\author{
Desempenho e características de carcaça de suínos aos $50 \mathrm{~kg}$ recebendo rações \\ com diferentes níveis de energia e reduzido teor de proteína bruta
}

\author{
Márcio Gilberto Zangeronimo ${ }^{2}$, Vinícius de Souza Cantarelli, Elias Tadeu Fialho 4 , \\ Nikolas de Oliveira Amaral ${ }^{5}$, Hebert Silveira ${ }^{6}$, José Augusto de Freitas Lima ${ }^{7}$
}

\begin{abstract}
The aim of this work was to evaluate the effects of different levels of metabolic energy (ME) in diets with a reduced level of crude protein $(\mathrm{CP})$ on the performance and carcass characteristics of growing swine. Thirty-two high-performance barrows (initial weight of 22.5 $\pm 1.43 \mathrm{~kg}$ and final weight of $50.81 \pm 2.54 \mathrm{~kg}$ ) were distributed in a randomized block design with four treatments (three levels of ME - 3,060, 3,230 and 3,400 kcal $/ \mathrm{kg}$ - in diets with $14 \% \mathrm{CP}$, and one control treatment with 3,230 kcal ME/kg and $18 \% \mathrm{CP}$ ) and four replicates. The diets were formulated with a true digestible basis of amino acids present in the feed, with methionine and threonine concentrations corrected as a function of lysine levels. The animals were slaughtered and their carcasses were studied. The ME levels did not affect the average weight gain, the feed:gain ratio, the backfat thickness or the loin eye area. A higher carcass yield and a higher carcass meat:fat ratio were observed in the animals that received the 3,230 and 3,060 kcal/kg ME levels. Compared to the control treatment, only the 3,400 kcal $/ \mathrm{kg} \mathrm{ME} \mathrm{level} \mathrm{had}$ a lower average daily feed intake. It is concluded that the $\mathrm{CP}$ level in diet should be reduced from $18 \%$ to $14 \%$ and the metabolizable energy level should be increased, thus reducing the feed intake and increasing the carcass meat:fat ratio without affecting the animal weight gain.
\end{abstract}

Index terms: Digestible amino acid, synthetic lysine, swine production, ideal protein.

\section{RESUMO}

Objetivou-se, neste trabalho, avaliar diferentes níveis de energia metabolizável (EM) em rações com reduzido teor de proteína bruta (PB) através do desempenho e características de carcaça de suínos em crescimento. Foram utilizados 32 suínos machos castrados de elevado ganho de peso (peso inicial de 22,5 $\pm 1,43 \mathrm{~kg}$ e final de $50,81 \pm 2,54 \mathrm{~kg}$ ), distribuídos em delineamento de blocos casualizados, com quatro tratamentos (três níveis de EM - 3060, 3230 e $3400 \mathrm{kcal} / \mathrm{kg}$ - em rações com 14\% PB e um tratamento controle com $3230 \mathrm{kcal}$ EM/kg e 18\% de PB) e quatro repetições. As rações foram formuladas com base na digestibilidade verdadeira dos aminoácidos presentes nos alimentos, sendo a metionina e a treonina corrigidas em função dos níveis de lisina. Os animais foram abatidos e tiveram suas carcaças estudadas. Os níveis de EM não afetaram o ganho de peso médio diário, a conversão alimentar, a espessura de toucinho e a área de olho de lombo. Observou-se maior rendimento e relação carne:gordura na carcaça dos animais que receberam os níveis de 3230 e $3060 \mathrm{kcal}$ EM, respectivamente. Comparado ao controle, apenas o nível de $3400 \mathrm{kcal} / \mathrm{kg}$ EM reduziu o consumo de ração médio diário. Conclui-se que o teor de PB da ração para suínos em crescimento pode ser reduzido de 18\% para 14\% e o nível de energia aumentado, propiciando menor consumo e maior relação carne: gordura sem afetar o ganho de peso dos animais.

Termos para indexação: Aminoácido digestível, lisina sintética, suinocultura, proteína ideal.

(Received in August 23, 2007 and approved in June 17, 2008)

\section{INTRODUÇÃO}

The use of the concept of ideal protein in diet formulation for pigs has been greatly recommended since it is linked to a reduction in the pollutant elements in the excrement (LLATA et al., 2002). However, the use of crystalline amino acids in diets with reduced crude protein levels has generated

\footnotetext{
${ }^{1}$ This Project was financed by FAPEMIG

${ }^{2}$ Veterinarian, Post-Doctor in Monogastric Nutrition - Veterinary Medicine Department of Lavras Federal University - UFLA - Post box 3037 - Zip code 37200-000 - Lavras, MG, Brazil - zangeronimo@ufla.br

${ }^{3}$ Zootechnist, Post-doctor in Monogastric Nutrition - Animal Science Department of Lavras Federal University - UFLA - Post box 3037 - Zip code 37200-000 - Lavras, MG, Brazil -viniciuscantarelli@yahoo.com.br

${ }^{4}$ Agro Engineer, PhD - Animal Science Department of Lavras Federal University - UFLA - Post box 3037 - Zip code $37200-000$ - Lavras, MG, Brazil fialho@ufla.br

${ }^{5}$ Zootechnist, Postgraduate student - Animal Science Department of Lavras Federal University - UFLA - Post box 3037 - Zip code $37200-000$ - Lavras, MG, Brazil - nikolasamaral@yahoo.com.br

${ }^{6}$ Agro Engineer, Postgraduate student - Veterinary Medicine Department of Lavras Federal University - UFLA - Post box 3037 - Zip code $37200-000$ -

Lavras, MG, Brazil - coachii@yahoo.com.br

7Zootechnist, Doctor in Monogastric Nutrition - Animal Science Department of Lavras Federal University - UFLA - Post box 3037 - Zip code 37200 000 - Lavras, MG, Brazil - jaflima@ufla.br
}

Ciênc. agrotec., Lavras, v. 33, n. 3, p. 903-910, maio/jun., 2009 
several questions, primarily concerning the metabolism of these nutrients.

In accordance to Partridge et al. (1985), no dietetic amino acid can compete for absorption sites in the gastrointestinal tract since they do not need to be discharged from the protein during the digestion process, and thus, a lower caloric amount may be used for feed. Thus, part of the liquid energy that could be used in this process is used for lipid synthesis, which is deposited in the form of fat that can reduce the quality of the animal carcass, and consequently the efficiency of the utilization of lysine for weight gain (LE BELLEGO et al., 2001; TUITOEK et al., 1997). On the other hand, there have reports that these amino acids can reach the sites of protein synthesis in the cells faster (BATTERHAN \& BAYLEY, 1989), and that they can interfere with animal growth due to the relative amounts present in the diets of animals or the energy required for their metabolism.

Some works have shown that nutrient manipulations in diets can influence the performance (AROUCA et al., 2007; ZANGERONIMO et al., 2009), nitrogen metabolism (OLIVEIRA et al., 2005; ZANGERONIMO et al., 2007a), physiologic parameters (ZANGERONIMO et al., 2007b) and carcass composition of swine (OLIVEIRA et al., 2006).

With regard to energy levels in diets, swine feed is composed mainly of corn and soybean meal, as these are energy sources that keep production costs lower. Moreover, energy levels can be manipulated to directly affect the utilization of other nutrients because they are linked to the regulation of consumption by the animals (REZENDE et al., 2006) and they interfere in the digestive processes of other nutrients, mainly amino acids (ALMEIDA et al., 2007).

Determination of the actual dietary requirements of animals is constantly needed when new lines that are selected for high weight gain appear and when new techniques for formulating diets are developed. Despite the enhanced ability of modern genotypes to increase their amounts of energy consumption, the effects of diets with high energy and suitable protein levels (mainly diets containing crystalline amino acids) on the performance and the carcass characteristics of swine are not well known. The objective of this work was to evaluate the effects of different metabolizable energy (ME) levels in reduced crude protein $(\mathrm{CP})$ diets by assessing the performance and carcass characteristics of growing swine.

\section{MATERIALAND METHODS}

The experiment was carried out at the Animal Science Department Experimental Farm of Lavras Federal University (UFLA), Lavras, in southern Minas Gerais, Brazil.
A total of 32 barrows from a hybrid line selected for its high percentage of lean meat (Toppigs genetics) with initial weights of $22.5 \pm 1.43 \mathrm{~kg}$ and an average final weight of $47.8 \pm 3.35 \mathrm{~kg}$ were utilized. The pigs were housed for 31 days in groups of two (an experimental unit) in pens with a concrete floor $(2.3 \times 1.5 \mathrm{~m})$ that were equipped with a semiautomatic feeder and drinker. All pigs were provided with ad libitum access to feed and water. The temperatures were controlled by using curtains on the sides of the hall, and the recorded maximum and minimum temperatures of the pens ranged from $21.4 \pm 2.0^{\circ} \mathrm{C}$ to $26.4 \pm 1.9^{\circ} \mathrm{C}$.

The experimental design was in randomized blocks (initial weight of animals) using three treatments and one control (made with a high crude protein content) for a total of four treatments with four replications, with two pigs per experimental plot.

For the performance assay, the experimental unit was represented by two animals, and for the carcass evaluation the experimental unit was represented by one animal.

The diets were formulated based on corn and soybean meal to contain different levels of metabolizable energy (MEs of 3,060; 3,230 and 3,400 kcal / kg), with a low level of crude protein (14\%). The diets were supplemented with amounts lysine, methionine and threonine on a true digestible basis that were compared to a conventional diet (the control) containing $1.03 \%$ digestible lysine, $3,230 \mathrm{kcal}$ $/ \mathrm{kg}$ ME and $18 \%$ crude protein. The amounts of methionine and threonine were adjusted to achieve the ideal profile in relation to the lysine content (Table 1), following the minimum recommendations of amino acids suggested by Rostagno et al. (2005).

The pigs were weighed at the beginning and the end of the experimental period to determine the average weight gain (AWG). The pens were cleaned daily, and the rations and waste were weighed twice daily to determine the consumption of each animal. The feed:gain ratio $(\mathrm{F}: \mathrm{G})$ was obtained via the relationship between the feed intake and the weight gain for the period. The daily intake of lysine (DIL) and the metabolizable energy intake (MEI) were obtained from the average daily feed intake (ADFI) and the efficiency of the utilization of lysine (EUL) through the relationship of DIL:AWG.

At the end of the 31-day experimental period, one pig from each pen that represented each treatment was subjected to fasting from solids for a 12-hour period; then, all of these were weighed, slaughtered and eviscerated for the evaluation of the carcasses. Immediately after evisceration, the carcasses were sawn in half lengthwise and weighed. The left half of the carcass of each pig was cooled to $7^{\circ} \mathrm{C}$ during 24 hours for the further evaluation of carcass characteristics. The measurements 
Table 1 - Compositions of the experimental diets.

\begin{tabular}{|c|c|c|c|c|}
\hline \multirow{2}{*}{ Ingredient $(\%)$} & \multicolumn{4}{|c|}{ Experimental diet } \\
\hline & Control & $3,060 \mathrm{kcal} / \mathrm{kg}$ & $3,230 \mathrm{kcal} / \mathrm{kg}$ & $3,400 \mathrm{kcal} / \mathrm{kg}$ \\
\hline Corn & 64 & 66 & 66 & 66 \\
\hline Soybean meal & 28 & 19 & 19 & 19 \\
\hline Soybean oil & 2.5 & 2.5 & 3.5 & 4.5 \\
\hline Cassava starch & 0.0 & 1.6 & 4.0 & 6.3 \\
\hline Dicalcium phosphate & 1.71 & 1.7 & 1.7 & 1.7 \\
\hline Limestone & 0.385 & 0.385 & 0.385 & 0.385 \\
\hline Iodate salt & 0.3 & 0.3 & 0.3 & 0.3 \\
\hline Sodium bicarbonate & 0.0 & 0.501 & 0.501 & 0.501 \\
\hline Vitamin supplement $^{1}$ & 0.1 & 0.1 & 0.1 & 0.1 \\
\hline Mineral supplement $^{2}$ & 0.1 & 0.1 & 0.1 & 0.1 \\
\hline L-lysine $\mathrm{HCl}(78 \%)$ & 0.3 & 0.705 & 0.705 & 0.705 \\
\hline DL-methionine (98\%) & 0.04 & 0.12 & 0.12 & 0.12 \\
\hline L-Threonine (98.5\%) & 0.06 & 0.25 & 0.25 & 0.25 \\
\hline Tylan $250^{3}$ & 0.04 & 0.04 & 0.04 & 0.04 \\
\hline Kaolim & 2.2 & 6.7 & 3.3 & 0.3 \\
\hline Total & 100 & 100 & 100 & 100 \\
\hline \multicolumn{5}{|l|}{ Calculated values } \\
\hline Metabolizable energy $\mathrm{kcal} / \mathrm{kg}$ & 3228 & 3067 & 3235 & 3399 \\
\hline Crude protein (\%) & 18.0 & 14.0 & 14.0 & 14.0 \\
\hline Available phosphorus (\%) & 0.343 & 0.327 & 0.327 & 0.327 \\
\hline Total calcium (\%) & 0.653 & 0.630 & 0.630 & 0.630 \\
\hline Digestible lysine (\%) & 1.029 & 1.390 & 1.390 & 1.390 \\
\hline Digestible methionine (\%) & 0.301 & 0.331 & 0.331 & 0.331 \\
\hline Digestible threonine (\%) & 0.660 & 0.716 & 0.716 & 0.716 \\
\hline
\end{tabular}

${ }^{1}$ Vitamin supplement contained in $1 \mathrm{~kg}$ of product for: vitamin A 8,000,000 UI; vitamin D3 1,200,000 UI; vitamin E $20 \mathrm{~g}$; vitamin K3 2,500 mg; vitamin B1 1,000 mg; riboflavin (B2) 4,000 mg; pyridoxine (B6) 2,000 mg; vitamin B12 20,000 mcg; niacin 25,000 mg; pantothenic acid $10 \mathrm{~g}$; folic acid $600 \mathrm{mg}$; biotin $50 \mathrm{mg}$; vitamin C $50 \mathrm{~g}$; antioxidant $125 \mathrm{mg}$.

${ }^{2}$ Mineral supplement contained in $1 \mathrm{~kg}$ of product for: selenium $500 \mathrm{mg}$; iron $180 \mathrm{~g}$; copper $20 \mathrm{~g}$; manganese $80 \mathrm{~g}$; zinc $140 \mathrm{~g}$; iodine $4 \mathrm{~g}$; cobalt $4 \mathrm{~g}$.

${ }^{3}$ Antibiotic tylosin

of the depth of the loin and the backfat thickness at the point P2 were taken. All measurements were made according to the Brazilian Method for Carcass Evaluation (ABCS, 1973). Subsequently, the calculations of the loin eye area (LEA) and the fat area (FA) were made according to Bridi \& Silva (2007), and for the determination of carcass yield the formula described by Guidoni (2000) was used:

$\mathrm{MPCC}=65.92-(0.685 \times \mathrm{BT})+(0.094 \times \mathrm{DL})-(0.026 \times \mathrm{HCW})$,

where:

MPCC: the meat percentage in the cooled carcass (\%); BT: the backfat thickness;
DL: the depth of loin; and

HCW: the hot carcass weight.

For the determination of the ratio of meat:fat for each animal, the equation proposed by Bridi \& Silva (2007) was used:

$$
\mathrm{RFM}=\mathrm{LEA} / \mathrm{SFA},
$$

where:

RFM = the ratio of meat / fat;

LEA $=$ the loin eye area $\left(\mathrm{cm}^{2}\right)$; and

$\mathrm{SFA}=$ the subcutaneous fat area $\left(\mathrm{cm}^{2}\right)$. 
The data were submitted to analysis of variance, using the Tukey test at 5\% to compare between the dietary levels of metabolizable energy. The control treatment was compared to other treatments by the Dunnett test at $5 \%$. All tests were performed using the statistical program SISVAR (Ferreira et al. 2000).

\section{RESULTS AND DISCUSSION}

The results for the average weight gain (AWG), the average daily feed intake (ADFI), the feed:gain ratio (F:G), the daily metabolizable energy DMEI), intake (the daily intake of lysine (DIL) and the efficiency of lysine utilization (ELU) are shown in Table 2.

There was no effect $(\mathrm{P}>0.05)$ of the level of metabolizable energy (ME) on the average weight gain. These data confirm the studies conducted by Rezende et al. (2006), who also have observed no effect of the dietary levels of ME on this variable in animals from 60 to $95 \mathrm{~kg}$.

Furthermore, research conducted by Llata et al. (2001) that evaluated the effect of the addition of fatty acids $(0,2$, 4 or $6 \%$ ) to diets with ME levels ranging from 3,310 to 3,580 $\mathrm{kcal} / \mathrm{kg}$ while maintaining the lysine:energy ratio constant on pigs from 40 to $60 \mathrm{~kg}$ has shown an increase in the weight gain of animals fed with increased dietary energy levels. The authors suggest that this may be related to a higher accumulation of fat in animals according to the higher energy intake, despite the reduction in feed intake.

The average daily feed intake decreased $(\mathrm{P}<0.05)$ with increasing levels of energy in the diet. Compared to control treatment, the levels of energy of 3,230 and 3,400 kcal/ $/ \mathrm{kg}$ (with the reduced level of crude protein) caused a reduction in feed intake $(\mathrm{P}<0.05)$. Since no differences were observed $(\mathrm{P}>0.05)$ in ME intake, these data are consistent with those obtained by Trindade Neto et al. (2005), who when assessing growing pigs between 23 and $48 \mathrm{~kg}$ of body weight have found that these animals can transform their feed intake into energy intake. These results are similar to the ones obtained by Rezende et al. (2006), who have observed a reduction in the ADFI due to the increase in the energy density of diets for growing pigs (60 to $95 \mathrm{~kg}$ ). Similarly, Santos et al. (2005), when evaluating gilts fed three levels of total lysine $(0.55,0.75$ and $0.95 \%)$ and three levels of ME $(3100,3250$ and $3400 \mathrm{kcal} / \mathrm{kg})$ with a content of $13 \%$ crude protein $(\mathrm{CP})$ have also observed a reduction in ADFI with an increase in the content of ME. However, some data are controversial, such as Ferreira et al. (2003), who have not observed differences in ADFI. However, these results may possibly have been due to the fact that these researchers assessed animals only up to $30 \mathrm{~kg}$. In this phase, the animals go through a physiological adaptation period of the gastrointestinal tract, which affects consumption to some extent.
The higher consumption of the diet by animals in the treatment of $3060 \mathrm{kcal} / \mathrm{kg}$ may be related to an increased consumption for amino acids since animals tend to increase consumption when fed a low energy diet. According Trindade Neto et al. (2005), when there is an excess of amino acids, the performance could be affected due to the metabolic implications involving the removal of this nutrient, which is above the demands for maintaining growth and protein synthesis in pigs reared under favorable conditions.

There was no effect $(\mathrm{P}>0.05)$ of the level of metabolizable energy and reduced level of $\mathrm{CP}$ of the diet on feed:gain ratio. Despite the lower ADFI in the treatment with the highest levels of metabolizable energy $(3,400 \mathrm{kcal} /$ $\mathrm{kg}$ ) compared to the control, this was not enough dietary energy to affect this variable.

On the other hand, Rezende et al. (2006) have suggested that there was an improvement in feed:gain because thay have observed a linear increase in $F: G$ with an icrease in the ME of diets. According to these authors, among the animal performance data usually evaluated in different experiments, the positive response of $F: G$ to an increased energy density of the diet has been the most consistent. However, this was not observed in this work.

Trindade Neto et al. (2005), when assessing growth in gilts, observed that as the levels of ME increased from 3,270 to $3,500 \mathrm{kcal} / \mathrm{kg}$ the feed:gain ratio decreased from 2.14 to 1.90 . According to Trindade Neto et al. (2005), the weight gain and feed conversion obtained with castrated males during the growing phase are indicative of the constant need to adjust diets to the nutritional requirements of swine, one should stick to the specifics selected for the production of pig meat.

In a study by Llata et al. (2002), the authors have observed that the decrease of CP by approximately two percentage units did not affect the performance of animals. According to these authors, if the reduction in $\mathrm{CP}$ was about three units there could have been a negative effect on performance if the diet was not supplemented with synthetic amino acids.

There were no differences $(\mathrm{P}>0.05)$ among the treatments tested in the total lysine intake, a similar result to that obtained by Trindade Neto et al. (2005). According to these authors, independent of the dietary energy levels they studied $(3,270$ and 3,500 kcal / kg), there were no differences in the average of lysine uptake $(\mathrm{P}>0.05)$ provided that the ratio of lysine: energy in the diet was maintained. In this experiment, despite the fact that a correction for this relationship was not made, the observed differences in feed intake were not enough to affect this variable.

Mascarenhas et al. (2002) have also observed no change in the daily consumption of lysine with an increase in the energy level from 3,350 to $3,650 \mathrm{kcal} / \mathrm{kg}$ with two 
lipid sources, soybean oil and coconut oil. In this study, the amino acid consumption remained above $22 \mathrm{~g} /$ day for finishing animals. This is below the expectations for pigs in this phase since in this experiment that consumption has been observed in growing animals.

For the daily metabolizable energy consumption, there was an effect $(\mathrm{P}<0.05)$ of all treatments compared to the control. This can be explained by the fact that the animals fed with high contents of crude protein had a higher intake of nutrients, especially amino acids. Comparing the levels of intake of metabolizable energy in diets with reduced crude protein, it was observed that there were no differences $(\mathrm{P}>$ $0.05)$ in this variable between these treatments. This last result is similar to that obtained by Rezende et al. (2006), who also have not observed an effect of the energy level (3,100 to 3,500 $\mathrm{kcal} / \mathrm{kg} \mathrm{ME})$ on the use of ME. As already discussed, this result implies that the dietary consumption may be related to an adjustment of animals to treatments in an attempt to satisfy their energy demands.

Overall, these results suggest that reducing crude protein in the diet does not affect performance, provided that the levels of the main limiting amino acids are maintained.

The results obtained for carcass yield, back fat thickness, longissimus muscle area and the meat:fat ratio are presented in Table 3. The energy levels in the diets did not influence $(\mathrm{P}>0.05)$ the back fat thickness and longissimus muscle area of the animal carcasses. However, differences were observed $(\mathrm{P}<0.05)$ for carcass yield and the meat:fat ratio. The highest yield was obtained when the ME level of 3,230 kcal/kg was used. This may be due to a lower deposition of visceral fat and subcutaneous neck.

These results confirm those obtained by LopezBote et al. (1997), Smith et al. (1999) and Stein et al. (1996), who have all observed an increase in carcass yield when assessing different levels of ME while maintaining the lysine:energy ratio for growing and finishing pigs.

Furthermore, Rezende et al. (2006) have found no effect of the level of ME on the carcass yield, the lean meat yield and the back fat thickness of finishing animals when maintaining the ratio of lysine:dietary energy. Ettle et al. (2003) have also observed no effect of dietary ME levels on the lean meat yield and animals carcass yield of animals slaughtered at $110 \mathrm{~kg}$. It is important to emphasize that the maintenance of the lysine:energy ratio provides a supply of amino acids to be metabolized in proportion to the energy intake level. In this work, high levels of energy may have favored the increase in visceral fat, and they may have also directed energy away from metabolizing amino acids that would be for protein synthesis towards the synthesis of lipids in the body.

Table 2 - Average weight gain (AWG), average daily feed intake (ADFI), feed:gain ratio (F:G), daily intake of lysine (DIL), daily metabolizable energy intake (DMEI) and efficiency of lysine utilization (ELU) for growing pigs receiving diets with low crude protein and various levels of metabolizable energy

\begin{tabular}{cccccccc}
\hline \multirow{2}{*}{ Variable analyzed } & \multicolumn{2}{c}{ Metabolizable energy level $(\mathrm{kcal} / \mathrm{kg})$} & \multirow{2}{*}{ Control } & & \multirow{2}{*}{$\mathrm{P}=$} & \multirow{2}{*}{$\mathrm{CV}(\%)$} \\
\cline { 2 - 4 } & 3060 & 3230 & 3400 & & & & 5.41 \\
AWG (g/day) & 865 & 800 & 846 & & 878 & 0.4639 & 6.88 \\
ADFI (g/day) & 1835 & 1705 & $1674 *$ & 1894 & 0.0456 & 10.27 \\
F:G & 2.14 & 2.13 & 1.98 & 2.16 & 0.1346 & 5.41 \\
DIL (g/day) & 25.5 & 23.7 & 23.3 & 23.3 & 0.6798 & 5.5 \\
DMEI (kcal/day) & $5628 *$ & $5514 *$ & $5691 *$ & 6114 & 0.3543 & 10.05 \\
ELU & 34.1 & 33.8 & 36.6 & 37.9 & 0.2748 & \\
\hline
\end{tabular}

* Treatment differs from control by Dunnett's test $(\mathrm{P}<0.05)$

${ }^{1}$ Significant linear regression with metabolizable energy $(P<0.05): y=-0.4735 x+3267.5 ; R^{2}=0.8881$

Table 3 - Carcass yield, back fat thickness, longissimus muscle area and the meat:fat ratio of growing pigs fed diets with a low CP content (14\%) that contained different levels of metabolizable energy (ME) ${ }^{1}$

\begin{tabular}{lccccccc}
\hline \multirow{2}{*}{ Variable } & \multicolumn{3}{c}{ ME level $(\mathrm{kcal} / \mathrm{kg})$} & \multirow{2}{*}{ Control } & & \multirow{2}{*}{$\mathrm{P}=$} & $\mathrm{CV}(\%)$ \\
\cline { 2 - 4 } & 3,060 & 3,230 & 3,400 & & & & \\
\hline Carcass yield $(\%)$ & $75.8 \mathrm{~b}$ & $79.0 \mathrm{a}$ & $76.7 \mathrm{~b}$ & 77.1 & 0.0001 & 2.76 \\
Backfat thickness $(\mathrm{cm})$ & 0.95 & 0.88 & 0.93 & 1.02 & 0.6557 & 12.05 \\
Longissimus muscle area $\left(\mathrm{cm}^{2}\right)$ & 29.0 & 28.8 & 30.9 & 30.3 & 0.2194 & 5.67 & 10.89 \\
Meat:fat ratio & $3.80 \mathrm{~b}$ & $4.02 \mathrm{~b}$ & $4.70 \mathrm{a}$ & 3.68 & 0.0183 & 10.83 \\
\hline
\end{tabular}

${ }^{*}$ Differs from the control treatment (diet with 3,230 kcal/kg ME and 18\% CP)

${ }^{1}$ Averages followed by different letters in the same row differ by the Tukey test $(\mathrm{P}<0.05)$ 
According to a review by Pettigrew \& Moser (1991), the addition of fat to the diet for growing-finishing pigs usually increases the content of fat in the carcass, but no work was mentioned that concerned the increase of carbohydrates in the diet.

The highest values of the ratio of meat:fat were observed $(\mathrm{P}<0.05)$ in the carcasses when the level of $3,400 \mathrm{kcal} / \mathrm{kg}$ of ME was used in diets with the low $\mathrm{CP}$ content; the meat:fat ratio of this energy level also differed from the control treatment $(\mathrm{P}<0.05)$. Despite the fact that the longissimus muscle area did not differ $(\mathrm{P}>0.05)$ among treatments, the difference in the meat:fat ratio results suggest that there was a greater synthesis of protein in the body during the growth of animals when the crude protein was reduced and the energy levels were increased as opposed to the results obtained by Lenise \& Jongbloed (1998) and Rademacher (1997). According to these authors, the reduction of crude protein and supplementation with crystalline amino acids in the diet results in greater fat accumulation due to the lower heat increment provided by these diets. In this experiment, the accumulation of lipids that was observed among the experimental treatments may be related to the energy deficiency in the diet, with the amino acids targeted for the synthesis of compounds that are energy deposited as fat in the carcass.

In general, the energy level of the diet is important when formulating diets with reduced levels of crude protein. Further studies are necessary in order to determine the best levels of metabolizable energy and whether should be maintained the relationships between energy levels, lysine and other amino acids in the diet.

\section{CONCLUSIONS}

The crude protein levels in the diets based on corn and soybean meal (formulated with lysine, methionine and threonine in a digestible basis) for growing pigs should be reduced from $18 \%$ to $14 \%$, and the levels of metabolizable energy should be increased from 3,230 to $3,400 \mathrm{kcal} / \mathrm{kg}$, providing a lower feed intake without affecting the weight gain of animals and a higher meat:fat ratio in the carcasses of the growth pigs.

\section{LITERATURE CITED}

AROUCA, C.L.C.; FONTES, D.O.; BAIÃO, N.C.; SILVA, M.A.; SILVA, F.C.O. Níveis de lisina para suínos machos castrados selecionados geneticamente para deposição de carne magra na carcaça, dos 95 aos $122 \mathrm{~kg}$. Ciência e Agrotecnologia, Lavras, v.31, n.2, p. 531-539, 2007.
ALMEIDA, E. C.; FIALHO, E. T.; CANTARELLI, V. S.; ZANGERONIMO, M. G.; PEREIRA, R. A. N.; RODRIGUES, P. B. Digestibilidade ileal e perdas endógenas de aminoácidos de dietas com óleo de soja para suínos em crescimento. Revista Brasileira de Zootecnia, Viçosa, v. 36, n. 4, p. 1045-1051, 2007. Suplemento.

\section{ASSOCIAÇÃO BRASILEIRA DE CRIADORES DE SUÍNOS. Método brasileiro de classificação de carcaças. Estrela, 1973. 17 p.}

BATTERHAN, E. S.; BAYLEY, H. S. Effect of frequency of feeding dietscontaining free or protein-bound lysine on the oxidation of [14C]phenylalanine by growing pigs. British Journal of Nutrition, Cambridge, v. 62, p. 647 $655,1989$.

\section{BRIDI, A. M.; SILVA, C. A. Métodos de avaliação da carcaça e da carne suína. Londrina: Midiograf, 2006. $97 \mathrm{p}$.}

ETTLE, T.; ROTH-MAIER, D. A.; ROTH, F. X. Effect of apparent ideal digestible lysine to energy ratio on performance of finishing pigs at different dietary metabolizable energy levels. Journal of Animal

Physiology and Animal Nutrition, München, v. 87, n. 7/ 8, p. 269-279, 2003.

FERREIRA, D. F. Análises estatísticas por meio do Sisvar para Windows versão 4.0. In: REUNIÃO ANUAL DA REGIÃO BRASILEIRA DA SOCIEDADE INTERNACIONAL DE BIOMETRIA, 45., 2000, São Carlos. Anais... São Carlos, SP: UFSCar, 2000. p. 255-258.

FERREIRA, R. A.; OLIVEIRA, R. F. M.; DONZELE, J. L. Redução da proteína bruta da ração para suínos machos castrados dos 15 aos $30 \mathrm{~kg}$ mantidos em termoneutralidade. Revista Brasileira de Zootecnia, Viçosa, v. 32, n. 6, p. 1639-1646, 2003.

GUIDONI, A. L. Melhoria de processos para a tipificação e valorização de carcaças suínas no Brasil. In: CONFERÊNCIA INTERNACIONAL VIRTUAL SOBRE A QUALIDADE DE CARNE SUÍNA, 1., 2000, Concórdia. Anais... Concórdia: Embrapa-CNPSA, 2000. p. 221-234.

JONGBLOED, A. W.; LENIS, N. P. Environmental concerns about animal manure. Journal of Animal Science, Champaign, v. 76, p. 2641-2648, 1998. 
LLATA, M. de la; DRITZ, S. S.; TOKACH, M. D.; GOODBAND, R. D.; NELSSEN, J. L. Effects of increasing L-lysine $\mathrm{HCl}$ in corn- or sorghum-soybean meal-based diets on growth performance and carcass characteristics of growing-finishing pigs. Journal of Animal Science, Champaign, v. 80, p. 2420-2432, 2002.

LE BELLEGO, L.; MILGEN, J. V.; DUBOIS, S.; NOBLET, J. Energy utilization of low-protein diets in growing pigs. Journal of Animal Science, Champaign, v. 79, p. 12591271, 2001.

LOPEZ-BOTE, C. J.; SANZ, M.; ISABEL, B.; AYALA, P. P.; FLORES, A. Effect of dietary lard on performance, fatty acid composition and susceptibility to lipid peroxidation in growingfinishing females and entire male pigs. Canadian

Journal of Animal Science, Lennoxville, v. 77, n. 2, p. 301-306, 1997.

MASCARENHAS, A. G.; DONZELE, J. L.; OLIVEIRA, R. F. M.; FERREIRA, A. S.; LOPES, R. S.; TAVARES, S. L.

Fontes e níveis de energia digestível em rações para suínos machos inteiros dos 60 aos 100 kg. Revista

Brasileira de Zootecnia, Viçosa, v. 31, n. 3, p. 1403-1408, 2002.

OLIVEIRA, V.; FIALHO, E.T.; LIMA, J.A.F.; BERTECHINI, A.G.; FREITAS, R.T.F. Teor de proteína no metabolismo do nitrogênio e da energia em suínos durante o crescimento. Ciência e Agrotecnologia, Lavras, v.29, n.4, p. 866-874, 2005.

OLIVEIRA, V.; FIALHO, E.T.; LIMA, J.A.F.; FREITAS, R.T.F.; BERTECHINI, A.G.; ARAUJO, J.S. Características de carcaça e peso de vísceras em suínos alimentados com rações contendo baixos teores de proteína bruta. Ciência Rural, Santa Maria, v. 36, n. 06, p. 1890-1895, 2006.

PARTRIDGE, I. G.; LOW, A. G.; KEAL, H. D. A note on the effect of feeding frequency on nitrogen use in growing boars given diets with varying levels of free lysine. Animal Production, Edingurgh, v. 40, n. 2, p. 375377, 1985.

PETTIGREW, J. E.; MOSER, R. L. Fat in swine nutrition. In: MILLER, E. R.; ULLREY, D. E.; LEWIS, A. J. (Eds.). Swine nutrition. Butterwrth-Heinemann: Stoneham, 1991. p. 133-146.
RADEMACHER, M. Manejo nutricional de suínos na fase de crescimento: terminação: conceitos básicos e novas idéias. In: ENCONTRO DE NUTRIÇÃO ANIMAL, 4., 1997, São Paulo, SP. Anais... São Paulo: Degussa Feed Additives, 1997. p. 1-11.

REZENDE, W. O.; DONZELE, J. L.; OLIVEIRA, R. F. M.; ABREU, M. L. T.; FERREIRA, A. S.; SILVA, F. C.; APOLÔNIO, L. R. Níveis de energia metabolizável mantendo a relação lisina digestível: caloria em rações para suínos machos castrados em terminação. Revista Brasileira de Zootecnia, Viçosa, v. 35, n. 3, p. 1101-1106, 2006.

ROSTAGNO, H. S.; ALBINO, L. F. T.; DONZELE, J. L.; GOMES, P. C.; OLIVEIRA, R. F.; LOPES, D. C.; FERREIRA, A. S.; BARRETO, S. L. T. Tabelas brasileiras para aves e suínos. Viçosa: UFV, 2002. $141 \mathrm{p}$.

SANTOS, J. M. G.; MOREIRA, I.; MARTINS, E. N. Exigências de lisina e energia metabolizável para marrãs de reprodução. Revista Brasileira de Zootecnia, Viçosa, v. 34, n. 6, p. 2298-2307, 2005.

SMITH, J. W.; TOKACH, M. D.; O'QUINN, P. R. Effects of dietary energy density and lysine:calorie ratio on growth performance and characteristics of growingfinishing pigs. Journal of Animal Science, Champaign, v. 77, p. 3007-3015, 1999.

STEIN, H. H.; HAHN, J. D.; EASTER, R. A. Effect of decreasing dietary energy concentration in finishing pigs on carcass composition. Journal of Animal Science, Champaign, v. 74, n. 1, p. 65, 1996. Supplement.

TRINDADE NETO, M. A.; MOREIRA, J. A.; BERTO, D. A.; ALBUQUERQUE, R.; SCHAMMASS, E. A. Energia metabolizável e lisina digestível para suínos na fase de crescimento, criados em condições de segregação sanitária. Revista Brasileira de Zootecnia, Viçosa, v. 34, n. 6, p. 1980-1989, 2005.

TUITOEK, J. K.; YOUNG, L. G.; LANGE, C. F.; KERR, B. J. Body composition and protein and fat accretion in various body components in growing gilts fed diets with different protein levels but estimated to contain similar levels of ideal protein. Journal of Animal Science, Champaign, v. 75, n. 6, p. 1584-1590, 1997. 
ZANGERONIMO, M.G.; FIALHO, E.T.; MURGAS, L.D.S.; FREITAS, R.T.F.; RODRIGUES, P.B. Desempenho e excreção de nitrogênio de leitões dos 9 aos $25 \mathrm{~kg}$ alimentados com dietas com diferentes níveis de lisina digestível e proteína bruta. Revista Brasileira de Zootecnia, Viçosa, v.36, n.5, p.1382-1387. 2007a.

ZANGERONIMO, M.G.; FIALHO, E.T.; MURGAS, L.D.S.; LIMA, J.A.F.; ROCHA, E.V.H.; ALVARENGA, R.R. Efeito de níveis de lisina digestível verdadeira e proteína bruta na dieta sobre parâmetros morfo- fisiológicos e utilização do nitrogênio em suínos na fase inicial. Ciência e Agrotecnologia, Lavras, v.31, n.2, p.506-513. 2007b.

ZANGERONIMO, M.G.; FIALHO, E.T.; LIMA, J.A.F.; GIRÃO, L.V.C.; AMARAL, N.O.; SILVEIRA, H.

Desempenho e características de carcaça de suínos dos 20 aos 50kg recebendo rações com reduzido teor de proteína bruta e diferentes níveis de lisina digestível verdadeira. Ciência Rural [on line], Santa Maria, 2009. 